\title{
Anal Papillary Hidradenoma
}

National Cancer Institute

\section{Source}

National Cancer Institute. Anal Papillary Hidradenoma. NCI Thesaurus. Code C96699.

A benign neoplasm arising from the perianal sweat glands. It presents as a cystic nodular lesion and is characterized by the presence of cystic and papillary structures. The papillary structures contain connective tissue and are covered by two layers of epithelium. 